\title{
Partisipasi Petani dan Efektivitas Gapoktan dalam Penguatan Lembaga Distribusi Pangan Masyarakat (LDPM) di Kecamatan Makarti Jaya Kabupaten Banyuasin
}

\section{Farmers' Participation and Gapoktan Effectiveness on Empowerment of Community Food Distribution Institution (LDPM) in Makarti Jaya District, Banyuasin Regency}

\author{
Sriati $^{1}$, Nukmal Hakim ${ }^{2}$, M. Arbi ${ }^{3}$ \\ ${ }^{123}$ Fakultas Pertanian, Universitas Sriwijaya, Palembang
}

\begin{abstract}
Empowerment activity for The Institution of Food Community Distribution Institution (abbreviated LDPM) is an empowerment program that was developed by government to facilitate distribution of mainfood raw material. In this program, The Government gave the Social Funding Asistant (namely "dana bantuan sosial”) to the cluster of famers group (abbreviated: Gapoktan) and guidance by Agricultural Extension Workers. The research was aimed to : (1) measure the level of farmer participation on LDPM program, (2) measure the level of effectiveness of LDPM Program and (3) analyze the correlation between famers participation level with efectiveness of LDPM Program. Research was conducted by survey method and continued by descriptve and corelation analysis. Respondents consisted of 45 farmers, from 9 clusters of Sri Rejeki's farmer groups (5 farmers each). The results showed that: (1) the participation level of farmers was in the medium category; (2) The level of LDPM Program effectiveness was in the high category, and (3) there was a significant positive correlation between farmers' participation level and LDPM program effectiveness level with the Spearman correlation coefficient $(R s)=0.479$ at $\boldsymbol{\alpha} \quad 0,01$.
\end{abstract}

Keywords: Effectiveness, farmer groups, farmers' participation, LDPM

\begin{abstract}
Abstrak
Kegiatan Penguatan LDPM merupakan suatu upaya memberdayakan Gabungan Kelompoktani (Gapoktan) dalam usaha distribusi pangan pokok. Dalam program Penguatan LDPM Pemerintah memberikan dana bantuan sosial, pembinaan dan bimbingan kepada Gapoktan melalui Penyuluh Pertanian Lapangan (PPL). Tujuan penelitian ini adalah : (1) mengetahui partisipasi petani dalam kegiatan penguatan LDPM di Kecamatan Makarti Jaya, (2) mengukur efektivitas Gapoktan dalam Penguatan LDPM, dan (3) menganalisis hubungan antara partisipasi petani dengan efektivitas Program Penguatan LDPM. Penelitian menggunakan metode survey, dengan analisis deskriptif dan analisis korelasi. Responden terdiri dari 45 petani yang diproleh dari 9 kelompok tani (setiap kelompok 5 petani) anggota Gapoktan Sri Rejeki di Kecamatan Makarti Jaya. Hasil penelitian yang diperoleh adalah: (1) partisipasi petani dalam program LDPM tergolong sedang (57,04\%), (2) efektivitas Gapoktan tergolong tinggi (79,92\%), dan (3) terdapat hubungan positif signifikan antara partisipasi petani dengan efektivitas Gapotan dalam program LDPM dengan nilai koefisien korelasi Peringkat Spearman $(\mathrm{Rs})=0,479$ pada $\alpha \quad 0,01$.
\end{abstract}

Kata kunci : Efektivitas, Gapoktan, partisipasi petani, LDPM

\section{Pendahuluan}

Kegiatan Penguatan Lembaga Distribui Pangan Masyaarakat (LDPM) merupakan satu upaya dalam mengatasi masalah ketahanan pangan yang berkembang saat ini. Melalui pogram Penguatan LDPM, Pemerintah menyalurkan Dana Bantuan Sosial kepada Gabungan Kelompok Tani (Gapoktan) dalam rangka memberdayakan kelembaagaan tersebut agar Gapoktan mempunyai kemampuan dalam melakukan kegiatan distribusi pangan, dan penyediaan cadangan pangan (Badan Ketahanan Pangan, Kementan, 2015).

Upaya pemberdayaan petani secara operasional dan terarah di Indonesia sebenarnya sudah berlangsung lama, meskipun istilah pemberdayaan mulai populer tahun 1990an. Kunci keberhasilan pembangunan dan pemberdayaan tidak hanya terletak pada kesesuaian kerjasama diantara semua unsur stakeholder, melainkan juga pada polapikir baru pemberdayaan yang diantaranya tercakup dalam 12 prinsip berikut : (1) debirokratisasi, (2) partisipasi, (3) privatisasi, (4) transparasi, (5) akuntabilitas, (6) desentralisasi, (7) pemberdayaan yang berdasar pada penguatan kemmpuan lokal, (8) meningkatan aspirasi hidup, (9) program yang berukuran besar, (10) program yang integralistik, (11) melibatkan perempuan, dan (12) pemanfaatan organisasi sosial (Nasdian, 2014). Ini berarti bahwa semua stakeholder dalam program pemberdayaan

${ }^{1}$ Korespondensi penulis 
masyarakat dituntut memiliki kinerja kelembagaan yang tinggi. Kelembagaan merupakan modal sosial yang penting dalam pembangunan (Tjondronegoro, 2005). Selain itu, selaras dengan peralihan paradigma pembangunan dari production centered development ke people centered development, maka salah satu prinsip yang harus dilaksanakan adalah partisipasi.

Partisipasi dimaknai sebagai keikutsertaan atau keterlibatan seseorang dalam kelompok sosial untuk melkukan kegiatan di masyarakat di luar pekerjaan/ profesinya (Theodorson dalam Mardikanto, 1993). Sementara Rogers dalam Levis (1996), menyebutkan bahwa partisipasi adalah proses pengambilan keputusan. Pengambilan keputusan memiliki pengertian yang luas, yaitu meliputi proses: perencanaan, pengambilan keputusan, pelaksanaan, evaluasi serta pemanfaatan hasil pembangunan. Menurut Slamet (1994) partisipasi dalam pembangunan dapat dibedakan atas 3 tahap, yaitu partisipasi pada tahap perencanaan, tahap pelaksanaan, dan partisipasi pada tahap pemanfaatan dan evaluasi program.

Partisipasi petani anggota kelompok tani yang tergabung dalam Gapoktan memiliki posisi penting dalam kegiatan Penguatan LDPM karena keterlibatan aktif dan kerjasama sesama anggota maupun pengurus Gapoktan akan mempengruhi efektivitas Gapoktan terebut. Tujuaan penelitian ini adalah : (1) mengetahui partisipasi petani dalam penguatan LDPM di Kecamatan Makarti Jaya, (2) mengukur efektivitas Gapoktan dalam Penguatan LDPM, dan (3) menganalisis hubungan antara partisipasi petani dengan efektivitas Program LDPM.

\section{Metode Penelitian}

Penelitian dilaksanakan dengan metode survey (Explanatory Survey) dengan tujuan menganalisis hubungan/pengaruh antar variabel penelitian dan menguji hipotesis. Survey dilakukan di Kecamatan Makarti Jaya, Kabupaten Banyu Asin, yaitu dengan mengkaji Partisipasi Petani dalam Kegiatan Penguatan LDPM di wilayah tersebut. Populasi dalam penelitian ini adalah masyarakat petani yang tergabung dalam Kelompoktani dan Gapotan Sri Rejeki di Kecamatan Makarti Jaya. Gapoktan Sri Rejeki terdiri dari 18 kelompoktani, dan yang pelaksana Program LDPM ada 9 kelompok tani. Sampel diambil secara acak (simple random sampling) dari 9 kelompok tani masing-masing 5 orang, sehingga jumlah sampel 45 petani.
Variabel penelitian meliputi: karakteristik reponden, partisipasi petani dalam program LDPM, dan efektivitas program LDPM. Karakteristik responden meliputi: umur, tingkat pendidikan, pengalaman, luas lahan, dan jumlah tanggungan keluarga. Tingkat Partisipasi petani dalam LDPM adalah keikutsertaan petani dalam setiap tahap kegiatan program Penguatn LDPM. Tingkat partisipasi diukur dari 3 tahap, yaitu tahap perencanaan, tahap pelaksanaan, serta pemantauan dan evaluasi. Setiap tahap terdiri atas 3 indikator, dan diukur dengan pemberian skor (Skala Likert). Efektivitas Program LDPM diukur melalui tingkat pencapaian tujuan LDPM sebagaimana dalam buku pedoman LDPM, yang ditentukan dari 3 indikator yaitu ; indikator hasil (outcome), indikator manfaat (benefit), dan indikator dampak (impact). Masingmasing indikator diukur melalui 3 pertanyaan, dengan memberikian skor 1 sampai 3. Skor 1 berarti capaian rendah, 2 sedang, dan 3 tinggi bagi setiap pengukuran.

Data yang dikumpulkan terdiri atas data primer dan data sekunder. Data primer meliputi data tentang variabel: karakteristik petani, partisipasi petani, dan efektivitas Program LDPM. Sementara data sekunder meliputi dokumen pendukung, baik dari intansi pemerintah maupun non pemerintah yang relevan dengan penelitian.

Data dianalisis secara deskriptif, ditmpilkan dalam bentuk tabel dan dianalisis secara mendalam. Untuk menganalisis hubungan antar variabel dilakukan dengan uji koefisien korelasi Peringkat Spearman. Pengukuran tingkat partisipasi petani dan efektifitas Program LDPM dilakukan dengan pemberian skor untuk setiap indikator (pertanyaan) dengan mengikuti pola skala Likert.

\section{Hasil dan Pembahasan}

\section{Karakteristik Responden}

Masyarakat di Makarti Jaya umumnya bekerja sebagai petani. Karakteristik responden (45 orang petani contoh) dalam penelitian ini mencakup umur, pendidikan, lama berusahatani dan luas lahan. Umur Responden berkisar dari 27 hingga 67 tahun dengan rata-rata 45,6 tahun. Sebagian besar $(60 \%)$ berumur lebih 40 tahun. Pendidikan responden berkisar mulai dari SD tidak tamat sampai Sarjana (S1), dan yang dominan yakni 23 orang $(51,11 \%)$ tamat SD. Kondisi ini memperlihatkan bahwa tingkat pendidikan petani termasuk katagori 
rendah tingkat kemampuan petani untuk menerima informasi yang disampaikan oleh penyuluh pertanian juga rendah. Pengalaman berusahatani petani contoh beragam, dari 4 sampai 55 tahun, dengan rata-rata 23 tahun, dan sekitar $80 \%$ berpengalaman lebih 10 tahun. Luas lahan petani contoh adalah 0,5 sampai 4 ha, dengan rata-rata 2,02 ha. Sebagian besar petani yakni 29 orang $(64,44 \%)$ mempunyai lahan 2 ha atau lebih. Gambaran terinci karakteristik petani contoh (reponden) diperlihatkan pada Tabel 1.

Tabel 1. Karakteristik Reponden di Kecamatan Makarti Jaya

\begin{tabular}{|c|c|c|c|}
\hline No. & Karakteristik & $\begin{array}{l}\text { Jumlah } \\
\text { (orang) }\end{array}$ & $\begin{array}{c}\text { Persen } \\
(\%)\end{array}$ \\
\hline \multirow[t]{5}{*}{1.} & Umur (tahun) & & \\
\hline & $27-40$ & 18 & 40,00 \\
\hline & $41-54$ & 13 & 28,89 \\
\hline & $55-67$ & 14 & 31,11 \\
\hline & Jumlah & 45 & \\
\hline \multirow[t]{7}{*}{2.} & Pendidikan : & & \\
\hline & Tidak sekolah & 4 & 8,89 \\
\hline & SD & 24 & 53,33 \\
\hline & SLP & 7 & 15,56 \\
\hline & SLA & 3 & 6,67 \\
\hline & S1 (sarjana) & 7 & 15,56 \\
\hline & Jumlah & 45 & 100,00 \\
\hline \multirow[t]{7}{*}{3.} & Luas garapan & & \\
\hline & (Ha) & 16 & 35,56 \\
\hline & $\leq 1$ & 14 & 31,11 \\
\hline & $1<\mathrm{X} \leq 2$ & 10 & 22,22 \\
\hline & $2<x \leq 3$ & 5 & 11,11 \\
\hline & $3 \leq x \leq 4$ & & \\
\hline & Jumlah & 45 & 100,00 \\
\hline \multirow[t]{7}{*}{4} & Pengalaman & & \\
\hline & bertani (tahun) & 10 & 22,22 \\
\hline & $4-13$ & 13 & 28,89 \\
\hline & $14-23$ & 15 & 33,33 \\
\hline & $24-33$ & 5 & 11,11 \\
\hline & $34-43$ & 2 & 4,44 \\
\hline & $\begin{array}{l}>43 \\
\text { Jumlah }\end{array}$ & 45 & 100,00 \\
\hline
\end{tabular}

\section{Partisipasi Petani dalam Penguatan LDPM}

Partisipasi petani dalam Penguatan LDPM diukur dalam 3 tahap yaitu tahap perencanaan, pelaksanaan, dan tahap pemantauan dan evaluasi. Hasil penelitian memperlihatkan bahwa partisipasi petani pada tahap perencanaan termasuk katagori rendah, skor rata-rata 4,87 (capaian 54,11\%). Kondisi ini ditunjukkan oleh partisipasi dalam kegiatan sosialisasi Program LDPM rendah (skor 1,22), dan persentase mengajukan pertanyaan katagori sedang (skor 1,73) dan persentase menghadiri sosialisasi sedang ( skor 1,91).

Pada tahap pelaksanaan, partisipasi petani termasuk katagori sedang, skor rata-rata 5,33 ( capaian $59,22 \%$ ). Hal ini terlihat bahwa dalam proses penyusunan Rencana Usaha Gapoktan, penyususnan Unit Usaha Distribusi, dan Penyusunan Unit Usaha pengolahan semuanya pada katagori sedang. Selanjutnya pada tahap Pemantauan dan Evaluasi, partisipasi petani termasuk katagori sedang, skor rata-rata 5,20 (capaian 57,78 \%). Kondisi ini ditunjukkan melalui skor pemantauan dan penilaian terhadap pelaksanaan program, dan penilaian evaluasi dampak program termasuk katagori sedang. Sementara keikutsertaan dalam penyusunan laporaan evaluasi program termasuk katagori rendah. Secara keseluruhan partisipasi petani dalam penguatan LDPM termasuk katagori sedang, dengan skor 15,40 (capaian 57,03\%). Gambaran secara terinci partisipasi petani dalam Program Penguatan LDPM diperlihatkan pada Tabel 2.

Dari Tabel 2 tampak bahwa dari 9 indikator pengukuran tingat partisipasi petani dalam penguatan LDPM, 7 diantaranya termasuk katagori sedang, sedangkan 2 lainnya yaitu pada kegiatan sosialissi program dan keikutsertan pada penyusunan laporan Evaluasi Program termasuk katagori rendah. Pada indikator sosialisasi program termasuk katagori rendah, hal ini tampak pada sebagian besar $(80 \%)$ responden menyatakan hanya 1 kali mengikuti sosialisasi. Sedangkan dalam kegiaatan penyusunan Laporan Evaluasi Program partisipasi rendah ditunjukkan oleh sebagian besar $(51,11 \%)$ responden menyatakan bahwa tidak ikut menyusun Laporan evaluasi, 33,33 \% ikut menyusun tapi tidak aktif, dan hnya 15,55 \% responden yang ikut menyusun Lporan Evalusi secara aktif.

Partisipasi petani pada tahap pelaksanaan program LDPM termasuk katagori sedang, hal ini diperlihatkan oleh keadaan bahwa sekitar $50 \%$ responden ikut dalam menyusun rencana Usaha Gapoktan, ikut menyusun Unit usaha distribusi, dan ikut menyusun Unit usaha pengolahan. Namun demikian diantara yang ikut tersebut, hanya 30\% yang ikut secara aktif.

Sub indikator pertama pada tahap pelaksanaan adalah Keikutsertaan Penyusunan Rencana Usaha 
Tabel 2. Tingkat Partisipasi Petani dalam Penguatan LDPM

\begin{tabular}{|c|c|c|c|}
\hline No & $\begin{array}{l}\text { Pengukuran/ } \\
\text { Indikator }\end{array}$ & Skor & Kriteria \\
\hline \multirow[t]{4}{*}{1} & \multicolumn{3}{|c|}{ IndikatorTahap Perencanaan } \\
\hline & $\begin{array}{l}\text { Kegiatan Sosialisasi } \\
\text { Program Penguatan- } \\
\text { LDPM }\end{array}$ & 1,22 & Rendah \\
\hline & $\begin{array}{l}\text { Persentase } \\
\text { Mengajukan }\end{array}$ & 1,73 & Sedang \\
\hline & $\begin{array}{l}\text { Pertanyaan } \\
\text { Persentase } \\
\text { Menghadiri }\end{array}$ & 1,91 & Sedang \\
\hline \multicolumn{2}{|c|}{ Jumlah Sosialisasi } & 4,86 & Rendah \\
\hline \multirow[t]{4}{*}{2} & \multicolumn{3}{|c|}{ IndikatorTahap Pelaksanaan } \\
\hline & $\begin{array}{l}\text { Keikutsertaan } \\
\text { Penyusunan Rencana } \\
\text { Usaha Gapoktan }\end{array}$ & 1,76 & Sedang \\
\hline & $\begin{array}{l}\text { Keikutsertaan } \\
\text { Penyusunan Unit } \\
\text { Usaha Distribusi/ } \\
\text { Pemasaran }\end{array}$ & 1,76 & Sedang \\
\hline & $\begin{array}{l}\text { Keikutsertaan } \\
\text { Penyusunan Unit } \\
\text { Usaha Pengolahan }\end{array}$ & 1,82 & Sedang \\
\hline \multicolumn{2}{|c|}{ Jumlah } & 5,33 & Sedang \\
\hline \multirow[t]{4}{*}{3} & $\begin{array}{l}\text { IndikatorTahap } \\
\text { Pemantauan dan } \\
\text { Evaluasi }\end{array}$ & & \\
\hline & $\begin{array}{l}\text { Pemantauan Terhadap } \\
\text { Pelaksanaan Program } \\
\text { LDPM }\end{array}$ & 1,76 & Sedang \\
\hline & $\begin{array}{l}\text { Keikutsertaan dalam } \\
\text { Penyusunan Laporan } \\
\text { Evaluasi Program }\end{array}$ & 1,64 & Rendah \\
\hline & $\begin{array}{l}\text { Mengevaluasi } \\
\text { Dampak Program } \\
\text { Penguatan-LDPM }\end{array}$ & 1,80 & Sedang \\
\hline \multicolumn{2}{|c|}{ Jumlah } & 5,20 & Sedang \\
\hline \multicolumn{2}{|c|}{ Skor Total } & 15,40 & Sedang \\
\hline
\end{tabular}

Gapoktan (RUG). Rencana Usaha Gapoktan (RUG) adalah rencana usaha yang disusun anggota kelompok tani dengan cara sistematis dan partisipatif yang digunakan sebagai dasar rekomendasi dari Tim Teknis dan Ketua Gapoktan dalam penggunaan dana Belanja Bantuan Sosial untuk kegiatan pembangunan sarana penyimpanan, kegiatan pembelian-penjualan, serta kegiatan pengadaan dan pendistribusian cadangan pangan. Skor partisipasi anggota kelompok tani pada indikattor Keikutsertaan Penyusunan RUG sebesar 1,76 dengan kategori sedang. Artinya, keikutsertaan petani dalam Penyusunan RUG yang diakukan oleh pengurus Gapoktan Sri Rezeki dan para petani anggota sudah cukup baik. Adapun kegiatan RUG Gapoktan Sri Rezeki yaitu simpan pinjam dan jual beli beras dan atau gabah.

Sub indikator kedua adalah keikutsertaan Penyusunan Unit Usaha Distribusi/ Pemasaran. Unit Usaha Distribusi/Pemasaran adalah unit usaha milik Gapoktan yang dibentuk berdasar keinginan, kebutuhan dan kesepakatan dari anggota Gapoktan, terutama guna membantu petani anggotanya dalam mendistribusikan gabah/beras/jagung waktu pada panen raya sehingga harga stabil di tingkat petani. Skor yang diperoleh dari sub indikator ini adalah sebesar 1,76 dengan kategori sedang. Artinya, keikutsertaan petani dalam Penyusunan Unit Usaha Distribusi/Pemasaran yang diakukan oleh pengurus Gapoktan Sri Rezeki dan para petani anggota sudah cukup baik. Hal ditunjukkan oleh keikutsertaan para petani dalam penyusunan Unit Usaha Distribusi/ Pemasaran pada program Penguatan-LDPM yang ikut berpartisipasi menyisihkan waktu untuk hanya ikut serta walau tidak aktif. Adapun kegiatan Unit Usaha Distribusi/Pemasaran yaitu jual beli beras dan/gabah.

Sub indikator ketiga pada tahap pelaksanaan adalah Keikutsertaan Penyusunan Unit Usaha Pengolahan. Unit Usaha Pengolahan adalah unit usaha milik Gapoktan yang dibentuk berdasar keinginan, kebutuhan dan kesepakatan dari anggota Gapoktan untuk dapat meningkatkan nilai jual produk gabah/ beras/jagung melalui kegiatan mengolah/menggiling/ mengepak/menyimpan sehingga dapat menambah keuntungan bagi Gapoktan. Skor partisipasi anggota kelompok tani yang diperoleh adalah 1,82 dengan kategori sedang. Keadaan ini ditunjukkan oleh adanya keikutsertaan para petani dalam penyusunan Unit Usaha Pengolahan pada program Penguatan-LDPM yang ikut berpartisipasi menalokasikan waktu untuk hanya ikut serta walau tidak aktif. Adapun kegiatan Unit Usaha Pengolahan Gapoktan Sri Rezeki yaitu penggilingan dan pengemasan menjadi produk olahan beras Makarti Cap Lumbung Pangan.

Tingkat partisipasi petani dipengaruhi karakteristik individu. Hasil penelitin menunjukkan bahwa karakteristik individu yang berhubungn nyata dengan tingkat partisipasi adalah : pendidikan formal ( $r s=0,345$, taraf nyata 0,05 ), sementara umur dan luas lahan tidak berhubungan nyata. 
Hasil penelitian ini sedikit berbeda dengan penelitian Berliana ( 2012), yang menunjukkan bahwa partisiasi petani pada program pemberdayaan (FEATI) termasuk katagori tinggi, dan untuk setiap tahapan dapat diketahui bahwa untuk tahap persiapan termasuk katagori tinggi, tahap pelaksanaan termasuk katagori sedang, dan tahap pemantauan/evaluasi termasuk katagori tinggi. Hal ini bisa dipahami, karena tingkat partisipasi seseorang dalam suatu kegiatan/program dipengaruhi oleh beberapa faktor antara lain karakteristik individu, jenis program/kegiatan, sistem sosial budaya setempat dan keaktifan agen pembaharu (Roger dan Shomaker, 1971). Tingkat partisipasi seseorang dalam kegiatan kelompok akan mempengaruhi pengetahuan dan wawasanya, serta pengalamannya terkait dengan kegiatan kelompok, yang pada akhirnya tingkat partisipasi akan mempengaruhi penilaiannya terhadap kinerja kelompok. Dalam penelitian ini penilaian terhadp kinerja kelompok dimaksudkan adalah penilaian petani terhadap efektivitas Gapoktan dalam Penguatan LDPM. Dapat dikatakan bahwa tingkat partisipasi diduga berkorelasi dengan efektivitas Gapoktan pada Penguatan LDPM. Penelitian lain tentang Partisipasi petani dalam replanting Kelapa sawit (Anggreany et al, 2016:7) menyimpulkan bahwa tingkat partisipasi petani pada program replanting untuk sub variabel tingkat peneraapn teknologi sebagian besar termasuk katagori rendah dan sedang, masing-masing (30,12\%) dn 39,76\%. Sementara untuk sub varibel pencatatan dan pengaturan keuangan partisipasi petani sebagian besar katagpori rendah (69,88\%), dan katagori sedang $25,30 \%$. Artinya secara umum partisipasi petani pada program replanting dalam katagori sedang.

Penelitian serupa tentang partisipasi Kelompok Perempuan Peduli Lingkungan dalam penanganan sampah menunjukan bahwa partisipasi responden dalam penanganan sampah (tahap perencanaan, pelaksanaan, dan monitoring evaluasi) tergolong katagori tinggi (lebih $70 \%$ ) (Ankesa et al. 2016:107).

\section{Efektivitas Gapoktan dalam Penguatan LDPM di Kecamatan Makarti Jaya}

Tingkat Keberhasilan Gapoktan dalam kegiatan Penguatan LDPM diukur melaui 3 indikator, yaitu indikator hasil, indikator manfaat, dan indikator dampak. Hasil penelitian memperlihatkan bahwa efektivitas Gapoktan dilihat dari indikator hasil termasuk kriteria tinggi dengan skor 7,96 (capaian 88,44\%), dari indikator manfaat termasuk katagori sedang, dengan skor 6,38 (capaian 70,88\%), dan dari indikator dampak termasuk katagori tinggi, skor 7,22 (cpaian 80,22\%). Secara keseluruhan efektivitas Gapoktan pada penguatan LDPM termasuk katagori tinggi, skor 21,56 (capaian 79,85\%). Data capaian secara terinci untuk setiap indikator keberhasilan diperlihatkan pada Tabel 3.

Pada Tabel 3 dapat diperlihatkan bahwa efektivitas Gapoktan termasuk katagori tinggi, artinya efektivitas Gapoktan sangat baik,. Hal ini tampak pada indikator hasil, indikator manfaat, dan indikator dampak. Bila ditelaah setiap sub indikator tampak bahwa indikator hasil dan dampak termasuk katagori tinggi sementara untuk indikator manfaat termasuk katagori sedang.

Efektivitas Gapoktan berdasarkan indikator hasil (outcome) sudah baik. Baik dalam peningkatan modal usaha, ketersediaan cadangan pangan dan juga peningkatan volume pembelian-penjualan beras maupun gabah. Gapoktan Sri Rezeki mengalami peningkatan dalam modal usaha dan kegiatan pendistribusian beras maupun gabah sekitar Rp 25.000.000. Peningkatan modal usaha Gapoktan mempengaruhi pembangunan pedesaan yang merupakan bagian pembangunan wilayah yang dapat mewujudkan kesejahteraan di desa tersebut dan mampu memberikan layanan prima kepada petani anggotanya. Skor yang didapat dari sub indikator ini adalah 2,98 termasuk kategori tinggi. Artinya modal usaha Gapoktan kini meningkat. Berdasarkan informasi dari ketua Gapoktan bahwa saat ini modal usaha Gapoktan lebih besar dari total dana bantuan sosial yang diterima Gapoktan Sri Rezeki.

Sub indikator kedua adalah ketersediaan cadangan pangan. Cadangan Pangan merupakan satu diantara unsur penting dalam keberadaan pangan yang mampu berfungsi mengatasi kesenjangan antara produksi dengan kebutuhan, disamping dapat pula dimaanfaatkan untuk menjamin tidak terjadinya kekurangan pangan sementara subgai akibat gangguan atau tidak adanya pasokan bahan pangan, sebagai contoh karena prasarana dan sarana transportasi putus akibat bencana alam. Skor yang didapat dari indikator ini adalah 2,47 dengan kategori tinggi. Artinya, sejauh ini cadangan pangan masih tersedia pada masa paceklik dan sudah mampu mencukupi kebutuhan pangan seluruh anggota.Cadangan pangan berupa stok gabah digudang milik Gapoktan yang sengaja disisihkan oleh anggota Gapoktan sebagai cadangan pangan nantinya pada saat musim peceklik (tidak ada musim panen). Untuk 
Tabel 3. Skor Efektivitas Gapoktan dalam Program LDPM

\begin{tabular}{|c|c|c|c|c|c|c|}
\hline No & Pengukuran & 1 & 2 & 3 & Skor & kriteria \\
\hline \multirow[t]{4}{*}{1} & $\begin{array}{l}\text { Tndikator hasil, } \\
\text { terdiri : }\end{array}$ & & & & 7,96 & Tinggi \\
\hline & $\begin{array}{l}\text { Peningkatan } \\
\text { modal usaha }\end{array}$ & 0 & 1 & 44 & 2,98 & Tinggi \\
\hline & $\begin{array}{l}\text { Keterediaan } \\
\text { cadangan } \\
\text { pangan }\end{array}$ & 3 & 18 & 24 & 2,47 & Tinggi \\
\hline & $\begin{array}{l}\text { Volume } \\
\text { pembelian- } \\
\text { penjualan beras/ } \\
\text { gabah }\end{array}$ & 0 & 22 & 23 & 2,51 & Tinggi \\
\hline \multirow[t]{4}{*}{2} & $\begin{array}{l}\text { Indikator } \\
\text { Manfaat, } \\
\text { terdiri : }\end{array}$ & & & & 6,38 & Sedang \\
\hline & $\begin{array}{l}\text { Pengelolaan } \\
\text { dana bansos }\end{array}$ & 1 & 17 & 27 & 2,58 & Tinggi \\
\hline & $\begin{array}{l}\text { Pengendalian } \\
\text { harga gabah }\end{array}$ & 45 & 0 & 0 & 1,00 & Rendah \\
\hline & $\begin{array}{l}\text { Akses pangan } \\
\text { pada mas } \\
\text { paceklik }\end{array}$ & 0 & 9 & 36 & 2,80 & Tinggi \\
\hline \multirow[t]{5}{*}{3} & $\begin{array}{l}\text { Indikator } \\
\text { Dampak, } \\
\text { terdiri : }\end{array}$ & & & & 7,22 & Tinggi \\
\hline & $\begin{array}{l}\text { Terkendalinya } \\
\text { harga pangan }\end{array}$ & 4 & 7 & 34 & 2,67 & Tinggi \\
\hline & $\begin{array}{l}\text { Terwujudnya } \\
\text { ketahanan } \\
\text { pangan }\end{array}$ & 2 & 23 & 20 & 2,40 & Tinggi \\
\hline & $\begin{array}{l}\text { Peningkatan } \\
\text { pendapatan } \\
\text { petani }\end{array}$ & 4 & 30 & 11 & 2,16 & Tinggi \\
\hline & $\begin{array}{l}\text { Total } \\
\text { Efektivitas } \\
\text { Gapoktan }\end{array}$ & & & & 21,56 & Tinggi \\
\hline
\end{tabular}

musim panen terakhir yaitu tahun 2015, ketersediaan cadangan pangan digudang milik Gapoktan Sri Rezeki berada pada kisaran 20-30 ton gabah. Jumlah gabah digudang sekarang telah banyak berkurang karena sudah musim paceklik sehingga petani mengambil stok gabah di gudang untuk pangan keluarga anggota Gapoktan. Adapun alasan para petani menyimpan dan menjual gabah di lumbung LDPM adalah karena keadaan rumah para petani yang sempit dan banyak tikus, sedangkan di lumbung LDPM selain keadaan gudang yang cukup besar dan tidak ada tikus. Untuk harga gabah sendiri lebih mahal di lumbung LDPM daripada pabrik lain, sehingga banyak petani menjual gabah ke lumbung LDPM karena lebih menguntungkan para petani. Sub indikator ketiga, yaitu peningkatan volume pembelian-penjualan beras/ gabah, diperoleh skor 2,51 dengan kategori tinggi. Artinya efektivitas Gapoktan menghasilkan peningkatan volume pembelian-penjualan beras dan gabah lebih tinggi dari tahun sebelumnya.

Berdasarkan indikator manfaat skor efektivitas Gapoktan dalam program termasuk kategori sedang, berarti cukup baik. Dari 3 indikator yaitu pengelolaan dana bansos, pengendalian harga gabah, dan akses pangan anggota Gapoktan, ada satu yang termaasuk katagori rendah yaitu pengedalian harga gabah, dan untuk pengelolan dana bansos dan akses pangan termasuk katagori tinggi.

Pengelolaan dana bantuan sosial yang diakukan oleh Gapoktan Sri Rezeki sudah baik. Alokasi dana bantuan sosial yang diterima Gapoktan Sri Rezeki diutamakan dalam pembangunan gudang, lumbung dan modal dalam pembelian-penjualan gabah dan/ beras (distribusi). Gapoktan juga mengalokasikan dana dalam pembelian sarana produksi (benih, pupuk dan pestisida) dengan sistem pinjam oleh anggota. Sistem pengembalian dilaksanakan pada waktu panen selanjutnya. Selain itu, Gapoktan juga mengalokasikan dana untuk biaya dalam pertemuan-pertemuan Gapoktan dan juga dalam kegiatan sosialisasi.

Indiktor ke dua yaitu pengendalian harga gabah pada Gapoktan Sri Rezeki dalam keadaan kurang baik. Berdasarkan informasi yang didapat dari ketua Gapoktan bahwa untuk sekarang harga jual gabah milik petani anggota Gapoktan lebih kecil daripada Harga Pembelian Pemerintah (HPP) yaitu sekitar Rp 3.200 hingga Rp 3.500. Salah satu tujuan dari Program Penguatan-LDPM ini adalah untuk meningkatkan nilai jual gabah (diatas harga HPP). Indikator ke 3 adalah akses pangan anggota Gapoktan, termasuk kategori tinggi, artinya tingkat akses pangan untuk seluruh anggota Gapoktan sudah tercukupi secara merata.

Berdasarkan indikator dampak (impact), efektifitas Gapoktan yang dilihat dari kestabilan harga gabah, terwujudnya ketahanan pangan, dan juga peningkatan pendapatan petani anggota Gapoktan, termasuk katagori tinggi. Kondisi ini diperkuaat oleh adanya kestabilan harga gabah yang diterima Gapoktan Sri Rezeki adalah sudah baik. Selain itu juga didukung oleh informasi dari ketua Gapoktan bahwa harga gabah untuk saat ini tidak stabil. Pada saat mengalami penurunan, harga gabah bisa mencapai Rp 3.000/ kg. Pada saat mengalami kanaikan harga, gabah bisa 
mencapai Rp 4.000/kg.

Sub indikator kedua dalam indikator dampak adalah terwujud ketahanan pangan, termasuk kategori tinggi. Artinya ketahanan pangan di wilayah Gapoktan Sri Rezeki adalah sangat baik. Hal ini diperkuat oleh informasi dari para petani bahwa dengan adanya program Penguatan - LDPM, ketahanan pangan masyarakat khususnya di daerah Gapoktan sudah terwujud. Petani tidak pernah mengalami kesukaran dalam memperoleh pangan.

Sub indikator terakhir dalam indikator dampak adalah peningkatan pendapatan petani, termasuk katagori sedang. Artinya peningkatan pendapatan petani di wilayah Gapoktan Sri Rezeki adalah cukup baik. Hal ini juga diperkuat oleh informasi dari para petani bahwa dengan adanya Program Pengutan-LDPM terjadi peningkatan pendapatan petani yang relatif tidak begiitu tinggi (hanya sedikit).

\section{Hubungan Tingkat Partisipasi Petani dengan Efektivitas Gapoktan pada Program LDPM di Kecamatan Makarti Jaya Kabupaten Banyuasin}

Hubungan partisipasi petani dengan efektivitas Gapoktan dalam Penguatan LDPM dianalisis berdasarkan sub variabelnya. Partisipasi terdiri dari tahapan yaitu perencanaan, pelaksanaan, dan pemantauaan dan evaluasi, sementara efektivitas Gapoktan dilihat dari indikator hasil, indikator manfaat dan indikator dampak. Hasil analisis korelasi peringkat Spearman, hubungan antara variabel partisipasi dan efektifitas Gapoktan dapat dilihat pada Tabel 4.

Hasil analisis pada Tabel 4 menunjukkan bahwa hubungan antara tingkat partisipasi anggota kelompok tani dengan efektivitas Gapoktan pada Penguatan-LDPM, dengan uji Korelasi Peringkat Spearman diperoleh nilai koefisien korelasi $r s=0,479$ signifikan pada pada taraf nyata $\alpha=0,01$. Artinya terdapat hubungan positif antara tingkat partisipasi anggota kelompok tani dengan efektivitas Gapoktan dalam Penguatan-LDPM di Kecamatan Makarti Jaya Kabupaten Banyuasin. Analisis selanjutnya terhadap tahapan partisipasi mana yang berhubungan lebih erat dengan efektifitas program, dapat diketahui bahwa partisipasi pada tahap pelaksaan lebih kuat korelasinya dengan efektivitas Gapoktan ( $\mathrm{rs}=0,478^{* *}$ ), kemudian tahap pemantauan $\left(\mathrm{rs}=0,416^{* *}\right)$, dan kemudian tahap perencnaan $(\mathrm{rs}=0,341 *)$. Demikianhalnya, korelasi antar variabel penentu tingkat partisipasi, diperoleh bahwa tahap pelaksanaan yang paling tinggi korelasinya ( $\mathrm{rs}=$ $\left.0,873^{* *}\right)$ dengan tingkat partisipasi, kemudian diikuti pemantauan dan evaluasi ( $\mathrm{rs}=0,805^{* *}$ ), serta tahap perencanaan $\left(\mathrm{rs}=0,779^{* *}\right)$. Hal ini dapat dijelaskan bahwa dalam tahap pelaksanaan indikator pengukuran lebih konkrit lebih bisa dipahami dan dan dirasakan oleh responden, sehingga memberikan variasi yang relatif besar dibandingkan dengan tahap pemantauan maupun perencanaan. Hal ini sejalan dengan penelitian Novita, et al., (2013), bahwa analisis terhadap tahapan partisipasi yaitu tahap perencanaan, tahap persiapan, tahap pelaksanaan, dan tahap evalusi, menunjukkan bahwa hanya tahap pelaksanaan yang berpengaruh nyata terhadap tingkat partisipasi., sedangkan tahap lainnya tidak berpengaruh nyata.

Dalam kaitannya hubungan dengan efektifitas Gapoktan, partisipai dalam pelaksaanaan lebih nyata (konkrit) berkaitan langsung dengan indikator-indikator efektivitas Gapoktan, sehingga korelasinya lebih tinggi. Efektivitas Gapoktan dalam program LDPM ditentukan oleh indikator hasil, indikator manfaat, dan indikator dampak. Hasil penelitian (Tabel 4) menunjukkan bahwa yang paling menentukan efektivitas program dari yang tertinggi adalah: indikator dampak, indikator hasil, dan indiktor manfaat. Sementara, korelasi (hubungan) indikator efektifitas program dengan tingkat partisipasi, yang tertinggi adalah indikator manfaat ( $\mathrm{rs}=0,449 * *$ ), indikator hasil ( $\mathrm{rs}=0,430^{* *}$ ), dan indikator dampak (rs $\left.=0,347^{*}\right)$. Selanjutnya korelasi antara faktor penentu (indikator) efektivitas program dengan efektivitas program, yang tertinggi adalah indikator dampak ( $\mathrm{rs}=$ $\left.0,843^{* *}\right)$, kemudian indikator hasil ( $\left.\mathrm{rs}=0,833^{* *}\right)$, dan terendah indikator manfaat ( $\left.\mathrm{rs}=0,687^{* *}\right)$.

Hasil penelitian ini sejalan dengan penelitian Novita et al., (2013), tentang partisipasi dan kinerja perempuan pada program FEATI, hasilnya menunjukkan bahwa terdapat hubungan yang kuat antara tingkat partisipasi dengan kinerja perempuan dengan koefisien korelasi $\mathrm{Rs}=0,69$. Hal serupa juga terlihat pada tingkat partisipasi, berdasarkan tahapannya menunjukkan bahwa pada seluruh tahapan (perencanaan, persiapan, pelaksanaan, dan evaluasi), semuanya berada pada katagori sedang. Perbedaan penelitian ini dengan penelitian Novita adalah bahwa dalam penelitian ini kinerja yang diukur adalah kinerja kelompok sebagai wahana belajar anggotanya. Sementara pada penelitian sebelumnya yang diukur adalah kinerja individu dalam kegiatan kelompok. Perbedaan ini akan berdampak pada 
Tabel 4. Nilai Koefisien Korelasi dan Signifikansi Hubungan antara Partisipasi Petani dengan Efektivitas Gapoktan dalam Penguatan LDPM

\begin{tabular}{llllll}
\hline & \multicolumn{3}{c}{ Variabel /indikator efektifitas Gapoktan } & \multirow{2}{*}{ Partisipasi } \\
\cline { 2 - 5 } & $\begin{array}{l}\text { Efektifitas } \\
\text { Gapoktan }\end{array}$ & $\begin{array}{l}\text { Indikator } \\
\text { Hasil }\end{array}$ & $\begin{array}{l}\text { Indikator } \\
\text { Manfaat }\end{array}$ & $\begin{array}{l}\text { Indikator } \\
\text { Dampak }\end{array}$ & \\
\hline Partisipasi & $0,479^{* *}$ & $0,430^{* *}$ & $0,449^{* *}$ & $0,347^{*}$ & 1,000 \\
Tahap Perencanaan & $0,341^{*}$ & 0,202 & $0,408^{* *}$ & 0,222 & $0,779^{* *}$ \\
Tahap Pelaksanaan & $0,478^{* *}$ & $0,421^{* *}$ & $0,296^{*}$ & $0,465^{* *}$ & $0,873^{* *}$ \\
$\begin{array}{l}\text { Tahap Pemantauan dan } \\
\text { evaluasi }\end{array}$ & $0,416^{* *}$ & $0,437^{* *}$ & $0,462^{* *}$ & $0,479 * *$ & $0,805^{* *}$ \\
Efektifitas Gapoktan & 1,000 & $0,833^{* *}$ & $0,687^{* *}$ & $0,843^{* *}$ & $\mathbf{0 , 4 7 9 * *}$ \\
\hline
\end{tabular}

Keterangan : ${ }^{*}$ signifikan pada $\alpha=0,05$.

** signifikan pada $\alpha=0,01$.

pengukuran dan analisis datanya.

Penelitian tentang hubungan kinerja kelompok dengan ketahanan pangan rumah tangga (Firdausi et al., 2014), menunjukkan bahwa kinerja kelompok berkorelasi positif dengan tingkat ketahanan pangan rumah tangga petani dengan koefisien korelasi 0. 532 . Hasil penelitian ini memperlihatkan bahwa kinerja kelompok berdampak pada kesejahtaeraan anggotanya. Oleh karena itu terkait dengan penelitian yang saya lakukan bahwa partisipasi anggota berkorelasi dengan efektivitas Gapoktan nantinya juga akan menunjang kesejahteraan pangan keluarga.

\section{Kesimpulan}

Tingkat partisipasi petani peserta Program Penguatan LDPM secara keseluruhan termasuk pada katagori sedang (57,78 \% dari skor maksimum). Partisipasi pada tahap perencanaan termasuk katagori rendah, tahap pelaksanaan dan juga tahap pemantauan dan evaluasi termasuk katagori sedang. Tingkat Keberhasilan (efektivitas) Gapoktan dalam Pelaksanaan Penguatan LDPM diukur melaui 3 indikator, yaitu indikator hasil, indikator manfaat, dan indikator dampak, secara umum termasuk katagori tinggi (capaian $79,85 \%$ ). Dari indikator manfaat termasuk katagori sedang, sementara dari indiktor indikator hasil dan juga indikator dampak termasuk katagori tinggi. Dari 9 indikator efektivitas Gapoktan, hanya 1 yang tergolong katagori rendah yaitu pengendalian harga gabah.

Hasil analisis dengan Uji Korelasi Peringkat
Spearman menunjukkan bahwa hubungan antara tingkat partisipasi anggota kelompok tani dengan efektivitas Gapoktan pada Penguatan-LDPM, diperoleh nilai koefisien korelasi $r s=0,479$ signifikan pada pada taraf nyata $\alpha=0,01$.

Artinya terdapat hubungan positif antara tingkat partisipasi anggota kelompok tani dengan efektivitas Gapoktan pada Program Penguatan Lembaga Distribusi Pangan Masyarakat (Penguatan-LDPM) di Kecamatan Makarti Jaya Kabupaten Banyuasin .Dengan kata lain semakin tinggi partisipasi petani anggota maka semakin tercapai tujuan Penguatan LDPM, baik dilihat dari indikator hasil, indikator manfat, maupun indikator dampak.

\section{Ucapan Terimakasih}

Ucapan terima kasih ditujukan pada Universitas Sriwijaya melalui Lembaga Penelitian, yang telah memberikan bantuan dana penelitian, dan seluruh responden, key informan, dan Penyuluh Pertanian Lapangan yang telah membantu pada terlaksananya penelitian ini.

\section{Daftar Pustaka}

Anggreany S, Muljono P, Sadono D. 2016. Partisipasi Petani dalam Replanting Kelapa Sawit di Propinsi Jambi. Jurnal Penyuluhan 12 (1) : 1-14.

Ankesa H, Amanah S, Asngari PS. 2016. Partisipsai Kelompok Perempuan Peduli Lingkungan dalam 
Penanganan Sampah di Sub DAS Cikapundung Jawa Barat. Jurnal Penyuluhan 12 (2) : 105-113.

Berlian M. 2014. Peran Peyuluh Pertanian Lapangan dan Partisipasi Petani dalam Program FEATI serta Pengaruhnya terhadap Pendapatan Petani di Kecamatan Banyuasin III Kabupaten Banyuasin. Jurnal Matematika, Saint dan Teknologi 15(1): 52-62.

Badan Ketahanan Pangan, Kementrian Pertanian, 2015. Pedoman Pelaksanaan Kegiatan Penguatan Lembaga Distribusi Pangan Masyarakat. Jakarta (ID): Badan Ketahanan Pangan Kementrian Pertanian Republik Indonesia.

Davis, J. And Goldberg. 1996. A Concept og Agribusiness. Boston (US): Harvard University.

Firdausi A, Kustiono D, dan MuhaiminAW.2014.Analisis Tingkat Kinerja Kelompoktani serta Hubungannya dengan Tingkat Ketahanan Pangan Rumah Tangga petani (Studi Kasus di Kecamatan Rasanae Timur Kota Bima). Jurnal AGRISE 14 (2): 118-126.

Levis, L.R. 1996. Komunikasi Penyuluhan Pertanian Pedesaan. Bandung (ID): PT. Citra Aditing Bakti.

Mardikanto, T. 1993. Penyuluhan Pembangunan Pertanian. Surakarta (ID): Sebelas Maret University Press.
Nasdian, FT. 2014. Pengembangan Masyarakat. Jakarta (ID): Yayasan Pustaka Obor Ondonesia.

Novita R, Koestiono D, dan Purnomo M. 2013. Tingkat Partisipasi dan Kinerja perempuan pada Program FEATI (Farmer Empowerment Throught Agricultural Technology and Information) di Kabupaten Malang. Habitat 24(2):133-140.

Pranaji, T. 2003. Diagnosa Kerapuhan kelembagaan Perekonomian Pedesaan. Forum Penelitian Agroekonomi 21(2) :126-142.

Prawirosentono. 1999. Kebijakan Kinerja Karyawan. Yogyakarta (ID): BPFE.

Rogers, EM. and FF.Shoemaker. 1971. Communication of Innovation. New York (US): New York Free Press.

Siegel, S. 1954. Non Parametric Statistics for Behavioral Sciences. New York (US): McGraw-Hill Book Company.

Slamet, Y. 1994. Pembangunan Masyarakat berwawasan Partisipasi. Surakarta (ID): UNS Press.

Sriati. 2012. Metode Penelitian Sosial. Palembang (ID): Penerbit Universitas Sriwijaya.

Tjondronegoro, SMP. 2005. Pembangunan, Modal dan modal Sosial, Jurnal Sosiologi Indonesia 07(2005): 10-14. 